DOI 10.32820/2079-1747-2019-24-74-79

УДК 621.791 .042

\title{
ПЦДВИЩЕННЯ ПРОДУКТИВНОСТІ РУТИЛОВИХ ЕЛЕКТРОДІВ
}

\author{
СІзотова. К.О. \\ Українська інженерно-педагогічна академія
}

Інформація про автора:

Ізотова Катерина Олександрівна: ORCID 0000-0002-6585-6681, itmzv@uipa.edu.ua, кандидат технічних наук, доцент кафедри інтегрованих технологій в машинобудуванні і зварювального виробництва, Українська інженерно-педагогічна академія; вул. Університетська, 16, м. Харків, 61003, Україна.

Метою розробки є підвищення продуктивності й зварювально-технологічних властивостей рутилових електродів за рахунок використання залізного порошку в якості дешевого й ефективного наповнювача при зварюванні плавленням.

Розроблено методику розрахунку показників продуктивності, що дозволяє визначити коефіцієнти наплавлення, розплавлювання й інші параметри електродів із залізним порошком у покритті, залежно від вмісту залізного порошку в покритті й режиму зварювання.

Досліджено механізм процесу утворення газових порожнин при багатошаровому наплавленні високопродуктивними електродами із залізним порошком. Показано, що процес відбувається в основному на стадії ванни й основною причиною їхнього утворення $\epsilon$ водень.

Введення феросиліцію до складу покриття помітно підвищує продуктивність наплавлення, але при цьому значно підвищується схильність до утворення пор. Введення $5 \%$ гематиту дозволило зняти проблему утворення пор.

Хімічний аналіз складу й випробування механічних властивостей наплавленого металу показують, що при використанні залізного порошку електроди перебувають на рівні вимог до типу Э46 за ГОСТ 9467. Виключено утворення пор і гарячих тріщин.

Розроблені рутилові електроди із залізним порошком на базі мінеральної сировини України, шо володіють підвищеними зварювально-технологічними властивостями й коефіцієнтом наплавлення 16-18 г/Агод. тил, тріщини.

Ключові слова: електрод, залізний порошок, зварювання, продуктивність, пори, ру-

Изотова $\boldsymbol{E} . \boldsymbol{A}$. «Повышение производительности рутиловых электродов».

Целью разработки является повышение производительности и сварочнотехнологических свойств рутиловых электродов за счет использования железного порошка в качестве дешевого и эффективного наполнителя при сварке плавлением.

Разработана методика расчета показателей производительности, позволяет определить коэффициенты наплавки, расплавления и другие параметры электродов с железным порошком в покрытии, в зависимости от содержания железного порошка в покрытии и режима сварки.

Исследован механизм процесса образования газовых полостей при многослойной наплавке высокопроизводительными электродами с железным порошком.

Показано, что процесс происходит в основном на стадии ванны и основной причиной их образования является водород.

Введение ферросилиция в состав покрытия заметно увеличивает производительность наплавки, но при этом значительно повышается склонность к образованию пор. Введение 5\% гематита позволило снять проблему образования пор.

Химический анализ состава и испытания механических свойств наплавленного металла показывают, что при использовании железного порошка электроды находятся на уровне требований к типу Э46 по ГОСТ 9467.

Исключено образования пор и горячих трещин. 
Разработанные рутиловые электроды с железным порошком на базе минерального сырья Украины, обладающих повышенными сварочно-технологическими свойствами и коэффициентом наплавки 16-18 г/Ач.

Ключевые слова: электрод, железный порошок, сварка, производительность, время, рутил, трещины.

Izotova $\boldsymbol{E}$. «Improving the performance of rutile electrodes»

The aim of the development is to increase the productivity and welding and technological properties of rutile electrodes through the use of iron powder as a cheap and effective filler in fusion welding.

A methodology for calculating performance indicators has been developed, it allows determining the coefficients of surfacing, melting and other parameters of electrodes with iron powder in the coating, depending on the content of iron powder in the coating and the welding mode.

The mechanism of the process of formation of gas cavities during multilayer surfacing with high-performance electrodes with iron powder is investigated. It was shown that the process occurs mainly at the stage of the bath and the main reason for their formation is hydrogen.

The introduction of ferrosilicon in the coating composition significantly increases the productivity of surfacing, but it significantly increases the tendency to form pores. The introduction of $5 \%$ hematite allowed to remove the problem of pore formation.

Chemical analysis of the composition and testing of the mechanical properties of the deposited metal show that when using iron powder, the electrodes are at the level of requirements for type E46 according to GOST 9467. The formation of pores and hot cracks is excluded.

Developed rutile electrodes with iron powder based on mineral raw materials of Ukraine, which have improved welding and technological properties and a deposit coefficient of $16-18 \mathrm{~g} /$ $\mathrm{Ah}$.

Keywords: electrode, iron powder, welding, productivity, time, rutile, cracks.

\section{Постановка проблеми}

В останні роки в Україні й за кордоном широко застосовуються електроди із залізним порошком у покритті, що забезпечують підвищену продуктивність ручного дугового зварювання [1]. Завдяки наявності залізного порошку в покритті й ретельно підібраному складу покриття подібні електроди мають досить гарні зварювально-технологічні властивості. Таким чином, широке застосування електродів з високим коефіцієнтом наплавлення відкриває більші можливості підвищення продуктивності ручного дугового зварювання.

Актуальним є задача розробити рутилові електроди із залізним порошком на базі мінеральної сировини України, шо володіють підвищеними зварювально-технологічними властивостями й коефіцієнтом наплавлення 16-18 г/Агод.

\section{Аналіз останніх досліджень}

У теперішній час приділяється велика увага створенню електродів із залізним порошком у покритті [2-4]. Основою для розробки електродів з підвищеною продуктивністю служили відомі покриття ОММ-5, ЦМ-7, МР-3, АНО-4, УОНИ-13 і ін.

Слід зазначити, що до високопродуктивних електродів із залізним порошком виявили значний інтерес і закордоном [5, 6].

У найближчі роки в нашій країні намічається збільшення виробництва залізного порошку для потреб електродного виробництва. Якщо прийняти, що продуктивність праці при зварюванні електродами із залізним порошком підвищиться в порівнянні зі звичайними еле- 
ктродами на 30-35 \%, то, як показали розрахунки, економія тільки заробітної плати складе близько 500 тис. грн. у рік.

Однак економічні переваги високопродуктивних електродів цим не вичерпуються. Електроди із залізним порошком і великою товщиною покриття відрізняються досить малими втратами металу на розбризкування при зварюванні. Наприклад, завдяки незначному розбризкуванню й гарній віддільності шлаків, полегшенню праці при очищенні швів від бризів $і$ шлаків, вартість зварених резервуарів знижується приблизно на $12 \%$.

\section{Постановка завдання досліджень}

Метою даної роботи є розробка нових високопродуктивних електродів типу Э46 на базі мінеральної сировини України для зварювання відповідальних конструкцій з вуглецевих сталей на змінному й постійному струмі, що забезпечують коефіцієнт наплавлення не менш 16 г/Агод. за рахунок використання залізного порошку в якості дешевого й ефективного наповнювача при зварюванні плавленням.

\section{Експериментальна частина}

Для досліджень використовувалися металеві електроди для ручного дугового зварювання вуглецевих і низьколегованих сталей, шо виготовляються способом обпресування. Для виготовлення дослідних партій використовували прес промислового виготовлення (рис.1). Стрижні електродів виготовляли зі сталевого зварювального дроту марки Св-08А за ГОСТ 2246 діаметром 5 і 6 мм. Застосовувалося покриття електродів рутилового виду, основу якого становить мінерал - рутил· $\mathrm{TiO}_{2}$, використовуваний у вигляді рутилового концентрату по ТУ 4-267-73.

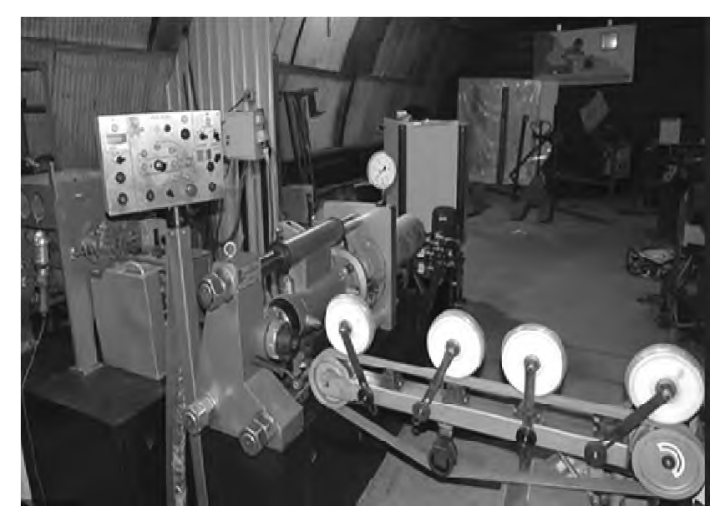

Рис.1 - Прес для виготовлення електродів
У якості розкислювача металу шва застосовувався феромарганець марки ФМн 1,0 за ГОСТ 4755 i феросиліцій марки Си-45 за ГОСТ 1415. Як наповнювач використовували залізний порошок марки ПЖ1 за ГОСТ 9849. Коефіціснт ваги покриття електродів становив 147-175\%. при товщині покриття на сторону 2,7-3,0 мм електродів діаметром 5 мм, i 3,0-3,6 мм - електродів діаметром 6 мм. Автоматичне визначення коефіцієнта маси покриття робили за допомогою приладу БИА-100. Виготовляли варіанти електродів $350 \%$ залізного порошку й системою покриття рутил-польовий шпат (табл.1).

Таблиця 1 - Склад покриттів дослідних електродів із залізним порошком в \%

\begin{tabular}{|c|c|c|c|}
\hline Найменування & \multicolumn{3}{|c|}{ Варіанти складу покритя } \\
\cline { 2 - 4 } компонентів & 1 & 2 & 3 \\
\hline Рутил & 12 & 19 & 34 \\
Польовий шпат & 34 & 27 & 12 \\
Феросиліцій & 4 & 4 & 4 \\
Залізний порошок & 50 & 50 & 50 \\
\hline
\end{tabular}




\section{Результати досліджень}

При вивченні різних металургійних систем було встановлено, шо продуктивність розплавлення електрода в значній мірі залежить від співвідношення основних компонентів у покритті. Було визначено, що наявність у покриттях однойменних компонентів, але взятих у різних співвідношеннях, не визначає однакові зварювально-технологічні властивості електродів (табл. 2).

Наявність залізного порошку в покритті обумовило деякі зміни загальноприйнятої методики визначення характеристик плавлення електродів. Тому при вивченні електродів із залізним порошком користувалися трохи зміненою методикою. Замість одного коефіцієнта розплавлення уведені два коефіцієнти розплавлення стрижня $\alpha_{\mathrm{pc}}$ i коефіцієнт розплавлення електрода $\alpha_{\mathrm{p} э}$.

Таблиця 2 - Продуктивність розплавлення дослідних електродів із залізним порошком

\begin{tabular}{|c|c|c|c|}
\hline $\begin{array}{c}\text { Варіант } \\
\text { електрода }\end{array}$ & $\begin{array}{c}\text { Коефіцієнт маси } \\
\text { покриття в \% }\end{array}$ & $\begin{array}{c}\text { Коефіцієнт наплав- } \\
\text { лення в г/Агод }\end{array}$ & $\begin{array}{c}\text { Продуктивність розплав- } \\
\text { лення електрода в г/год }\end{array}$ \\
\hline 1 & 180 & 13,2 & 3660 \\
2 & 180 & 17,1 & 5030 \\
3 & 180 & 18,4 & 5320 \\
\hline
\end{tabular}

Наявність залізного порошку в покритті обумовило деякі зміни загальноприйнятої методики визначення характеристик плавлення електродів. Тому при вивченні електродів із залізним порошком користувалися трохи зміненою методикою. Замість одного коефіцієнта розплавлення уведені два коефіцієнти розплавлення стрижня $\alpha_{\mathrm{pc}}$ i коефіцієнт розплавлення еле-

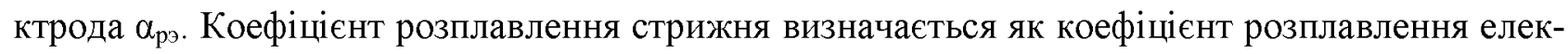
тродів, покриття яких не містить залізного порошку:

$$
\alpha_{p 3}=\frac{G_{c}}{I t} 2 / A \psi,
$$

де $G_{c}$ - вага розплавленого стрижня в $\Gamma ;$ - сила зварювального струму в А; $t$ - час горіння дуги в год.

Коефіцієнт розплавлення електрода, що враховує вагу розплавленого порошку при плавленні електрода, визначається по формулі:

$$
\alpha_{p \ni}=\frac{G_{c}+g_{\varkappa \cdot n}}{I t} 2 / A \varphi
$$

де $g_{ж . n}$ - вага залізного порошку в розплавленій частині покриття в г.

Коефіцієнт втрат розраховується по формулі:

$$
\varphi=\left(1-\frac{G_{u}}{G_{c}+g_{\varkappa . n}}\right) 100 \%,
$$

де $G_{\mu}$ - вага наплавленого металу в г.

Продуктивність розплавлення електрода із залізним порошком у покритті визначається по формулі: 


$$
g_{p}=\alpha_{p \ni} 2 / A \varphi
$$

У результаті серії експериментів був розроблений оптимальний варіант електрода, склад покриття й механічні властивості якого представлені в табл.3. Хімічний склад наплавленого металу в \%: 0,09-0,12 C; 0, 62-0,80 Mn; 0, 28-0,40 Si; 0,025-0,031 S; 0,023-0,030 P.

Дані електроди мають наступні характеристики: коефіцієнт маси покриття дорівнює 140\%, коефіцієнт розплавлення 18 г/Агод, коефіцієнт наплавлення 17, 8 г/Агод, коефіцієнт втрат 4-6\%.

Таблиця 3 - Склад покриття й механічні властивості електродів

\begin{tabular}{|ll|ll|}
\hline Склад покриття в \% & \multicolumn{3}{|c|}{ Механічні властивості } \\
\hline Рутил & 17 & Межа міцності в МПа & $541-546$ \\
Польовий шпат & 10 & Відносне подовження в \% & $22,2-26,7$ \\
Залізний порошок & 61 & Відносне звуження в \% & $53,3-67,9$ \\
Феромарганець & 5 & Ударна в'язкість у Дж/см & \\
Феросиліцій & 4 & у вихідному стані & $145-175$ \\
Целюлоза & 3 & після штучного старіння & $62-116$ \\
\hline
\end{tabular}

Аналізуючи отримані дані, можна зробити висновок, що характеристики плавлення електрода й механічні властивості наплавленого металу досить високі. При цьому забезпечується гарне формування зварних швів хороше відділення шлаку (рис. 2).

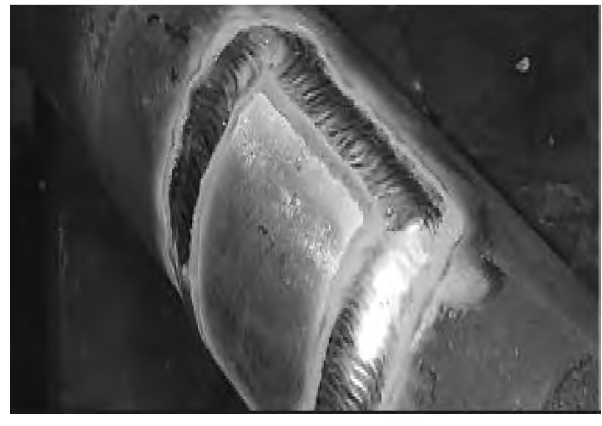

Рис.2 - Зовнішній вигляд зварного з'єднання
Наявність гематиту в покритті в кількості 6\% дозволило повністю виключити утворення газових порожнин, незалежно від гранулометричного складу залізного порошку. Подальша перевірка електродів 3 гематитом у покритті дозволила встановити, що $5 \%$ гематиту досить для повного й надійного усунення газових порожнин у наплавленому металі. Випробування показали, що ці електроди мають високі зварювально-технологічні властивості й високі показники продуктивності - коефіцієнт наплавлення у межах 14-16 г/Агод.

По механічних властивостях електроди задовольняють вимогам, пропонованим до типу електродів Э46 за ГОСТ 9467.

Викладені результати експериментів дозволили встановити наступне. Для придушення реакцій, що ведуть до утворення газових порожнин, потрібно гематиту менше $5 \%$, якщо використовується більше окислений залізний порошок. Якщо покриття містить феросиліцій, що підвищує коефіцієнт наплавлення, те, щоб виключити утворення газових порожнин, потрібно вводити в покриття більше $5 \%$ гематиту.

\section{Висновки}

Практично підтверджена залежність продуктивності наплавлення від вмісту рутилу, польового шпату й FeMn. Використовуючи розрахунковий метод можна визначити продуктивність наплавлення електродів із залізним порошком у покритті конкретного складу 
Результати аналізу хімічного складу й механічних випробувань наплавленого металу показують, що при використанні залізного порошку й вмісті вуглецю в металі шва не вище 0,13\%, механічні властивості перебувають на рівні вимог до електродів типу Э46 за ГОСТ 9467.

Розроблені рутилові електроди із залізним порошком і рудо-мінеральною сировиною України, володіють підвищеним до 16-18г/Агод коефіцієнтом наплавлення й поліпшеними зварювально-технологічними властивостями.

\section{Список використаних джерел:}

1. Игнатченко В. П. Состояние и тенденции развития производства сварочных материалов в странах СНГ / В. П. Игнатченко, А. И. Бугай // Сборник докладов 1-ой Международной конференции по сварочным материалам стран СНГ. - Краснодар, 22-26 июня 1998 г. - М., 1998. - С. 15-20.

2. Влияние степени окисленности на особенности структуры и механические свойства металла шва, выполненного электродами с рутиловым и ильменитовым покрытиями / И. К. Походня, Коляда Г.Е., Явдощин И.Р. [и др.] // Автоматическая сварка. - 1982. - № 2. - С. 10-14.

3. Сидлин 3. А. Современные ильменитовые электроды / 3. А. Сидлин. - М. : Ротекс, 2002. -30 с.

4. Явдощин И. Р. Новые электроды ИЭС им. Е.О. Патона для сварки конструкций из низкоуглеродистых и низколегированных сталей / И. Р. Явдощин // Сборник докладов 1-ой Международной конференции по сварочным материалам стран СНГ. - Краснодар, 22-26 июня 1998 г. - М., 1998. - С. 135-137.

5. Farias J.P. The effect of magnesium content on the arc stability of SMAW E7016-C2L/8016-C2 covered Electrodes / J. P. Farias, A. M. Quites, E. Surian // Welding Journal. - 1997. - no 5. - Pp. 124-250.

6. Jariyabon M, Davenport AJ, Ambert R, Connolly BJ, Willians SW, Price DA (2007). The effect of welding parameters on the corrosion behaviour of friction stir welded AA2024 - T351. Corrosion Sci., 49: $877-909$.

\section{References}

1. Ignatchenko, VP \& Bugaj, AI 1998, 'Sostojanie i tendencii razvitija proizvodstva svarochnyh materialov V stranah SNG', Sbornik dokladov 1-oj Mezhdunarodnoj konferencii po svarochnym materialam stran SNG, Moskva, pp. $15-20$.

2. Pohodnja, IK, Koljada, GE, Javdoshhin, IR, Markasheva, LI \& Svecinskij, VG 1982, 'Vlijanie stepeni okislennosti na osobennosti struktury i mehanicheskie svojstva metalla shva, vypolnennogo jelektrodami s rutilovym i ilmenitovym pokrytijami', Avtomaticheskaja svarka, no. 2, pp. 10-14.

3. Sidlin, ZA 2002, Sovremennye ilmenitovye jelektrody, Roteks, Moskva.

4. Javdoshhin, IR 1998, 'Novye jelektrody IJeS im. E.O. Patona dlja svarki konstrukcij iz nizkouglerodistyh i nizkolegirovannyh stalej', Sbornik dokladov 1-oj Mezhdunarodnoj konferencii po svarochnym materialam stran SNG, Moskva, pp. 135-137.

5. Farias, JP, Quites, AM \& Surian, E 1997, 'The effect of magnesium content on the arc stability of SMAW E7016-C2L/8016-C2 covered Electrodes', Welding Research Supplement, Welding Journal, no. 5, pp. 124-250.

6. Jariyabon M, Davenport AJ, Ambert R, Connolly BJ, Willians SW, Price DA (2007). The effect of welding parameters on the corrosion behaviour of friction stir welded AA2024 - T351. Corrosion Sci., 49: $877-909$.

Стаття надійшла до редакції 17 жовтня 2019 р. 